JOURNAL OF SECURITY AND SUSTAINABILITY ISSUES

ISSN 2029-7017/ISSN 2029-7025 (online)

2020 Volume 9 January

http://doi.org/10.9770/jssi.2020.9.J(16)

Scopus

\title{
BARRIERS IN WAY TOWARDS QUALITY EDUCATION: POVERTY, FERTILITY RATE AND INCREASING POPULATION
}

\author{
Waleerak Sittisom \\ Suan Sunandha Rajabhat University, Bangkok, Thailand \\ E-mail: waleerak.si@ssru.ac.th
}

Received 27 March 2019; accepted 18 November 2019; published 30 January 2020

\begin{abstract}
Quality of education must be maintained in any country as it has become impossible to survive and growth without quality education. There are some aspects that may affect the quality of education such as poverty, fertility rate and population increase. This study has been designed in order to find out and explore the impact of these aspects on quality of education. The data was collected for this purpose from Asian countries for the time period of 29 years and from reliable sources. For analysis purpose, unit root test was employed to find order of integration and stochastic properties of variables, cointegration test was applied in order to find out the cointegrated relationships between the variables, coefficient estimation test was applied in order to measure these relationships and finally Granger casualty test was applied so that the casual relationships may be found out among the variables. The results of these tests indicated that poverty and population increase have significant negative impact on quality of education while the impact of fertility rate has been found insignificant. In the same way, the impact of one control variable, per capita income has been found significant. In the last some important implications and limitations have been discussed by the author.
\end{abstract}

Keywords: quality of education; poverty; fertility rate; increasing population, Asia

Reference to this paper should be made as follows: Sittisom, W. (2020). Barriers in way towards quality education: poverty, fertility rate and increasing population, Journal of Security and Sustainability Issues, 9(January), 215-227. http://doi.org/10.9770/jssi.2020.9.J(16)

JEL classification: I25

\section{Introduction}

Education is the backbone of economic prosperity and plays fundamental role in the political and social growth of any nation (Jermsittiparsert \& Sawasdee, 2012; Humbatova, Gadim-Oglu Hajiyev, 2019; Girdzijauskaite, Radzeviciene, Jakubavicius, 2019). Amid enough interest in human capital, no nation can achieve realistic financial reform. Education enhances people's perception not just of themselves, but of culture as well. It improves the quality of living and offers people and society economic advantages. Education is accepted as a basic human right. Given the value of learning, the Transparency International 2017 had alarming estimates. As shown by Transparency International, $66 \%$ of countries have literacy levels below the average score of 43 . Amongst the worst cases, Central Asian countries have an average literacy rate of 34. South East Asia is among most populated areas of the world yet quality of education in this region is very poor. A range of factors, such as poverty, fertility rate and increasing population, influence Asia's quality of education (Roser \& Ortiz-Ospina, 2016).

The World Economic Forum reports that it was just five years earlier that only 35 people owned assets were comparable to $50 \%$ of the developing world. The disparity has increased sharply already. Today, 8 citizens own wealth equal to half of the world's poor wealth, making up 3.6 billion people living in poverty (Gap, 2017; Hardoon, 2017). Poverty is a persistent burden for kids and families in all societies that can conflict with positive transition to educational roles, including college achievement. Children who grow up in minimal-income families are always at threat of academically and socially difficulty as well as bad health and well-being, which can in effect hinder 
JOURNAL OF SECURITY AND SUSTAINABILITY ISSUES

ISSN 2029-7017/ISSN 2029-7025 (online)

2020 Volume 9 January

http://doi.org/10.9770/jssi.2020.9.J(16)

educational performance. Thus, in developing nations, children's in neediness are at a lot more serious danger of never going to class than wealthier kids, and these distinctions are wide (for instance, in an example of 80 nations, $12 \%$ of kids in the top quintile of family units never went to class, while $38 \%$ of kids in the least fortunate quintile never went to class (Latif, Choudhary, \& Hammayun, 2015).

Increased fertility is also invisibly associated with the quality of education. Education not only give awareness of gaining basic necessities of life but also decreasing fertility (Güneş, 2016). This decrease in fertility leads to lower population growth hence, availability of quality education is enhanced (see figure 1).

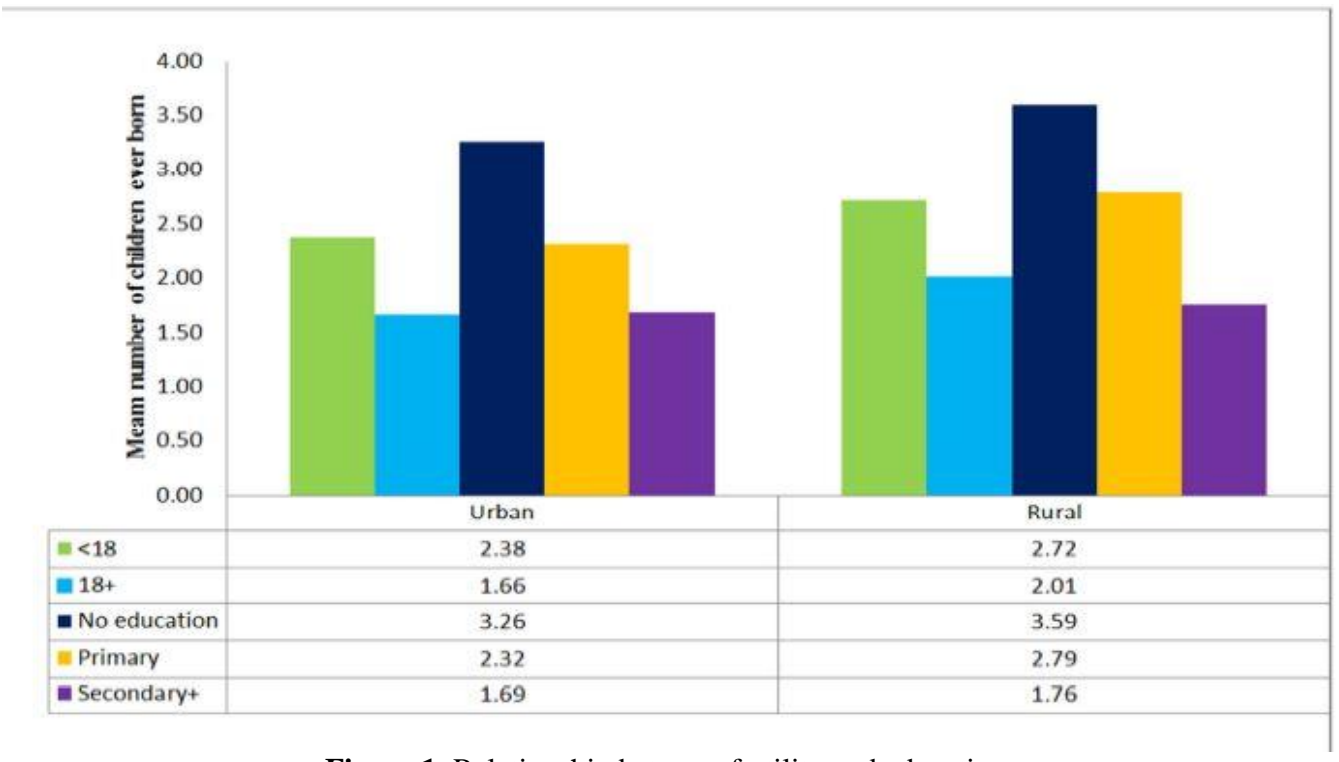

Figure 1. Relationship between fertility and education.

Source: (Haq, 2018)

Level of quality of education is declining in Asia due to various factors like poverty, increased fertility and population. This problem is not only in Asia but in other continents as well. If this factor would not be resolved quickly it will further deteriorate the situation and will become root cause of other social issues. Previous studies have been done in assessing factors influencing quality of education in different regions of the world. In this study, we will discuss the impact of these factors especially in Asia. So, following are the objectives of present study:

1. To analyse the impact of poverty on the quality of education.

2. To analyse the impact of increased fertility on the quality of education.

3. To analyse the impact of increased population on the quality of education.

In the present study, we discuss the impact of poverty, increased fertility and population in prospective of Asia. This study will help to undines the areas where special attention need to be focus to eradicate the negative impacts of factors under study in reference to quality of education.

\section{Literature Review}

(Mankiw, Romer, \& Weil, 1992) demonstrated that the welfare of the individuals increases when a worker gain education. This is termed as growth model presented by (Solow, 1956). This welfare of individuals was reaffirmed in Endogenous Growth Theory (Aghion, 1999; Aghion \& Howitt, 1992). There are various studies that proves Endogenous Growth Theory as the education impacts a positive role in the growth of individual (Aghion, 1999; 
JOURNAL OF SECURITY AND SUSTAINABILITY ISSUES

ISSN 2029-7017/ISSN 2029-7025 (online)

2020 Volume 9 January

http://doi.org/10.9770/jssi.2020.9.J(16)

Hanif \& Arshed, 2016; Hanushek \& Kimko, 2000). Better education highly boosts up the efficiency, easier for the individual to adapt new technologies and gain of greater price in return of effort. Fields et al., describes the relationship between poverty and education in lower income countries. The increase education helps in gaining better skill thus getting more wage and reducing poverty (Fields, 1980).

\subsection{Impact of poverty on the quality of education}

Efendi, et al., (2019) performed a secondary study to assess relationship between poverty and education. Data was obtained from BPS and SEKI institutes and was analysed by Ordinary Least Squares (OLS) method. The results of the study shows that the decreased quality of education in Indonesia leads to increased poverty $\mathrm{R}$ squared value=88.5 (Efendi, Indartono, \& Sukidjo, 2019). A study performed by Mahon (2016) to check the relationship between socioeconomic status and quality of education. Students with lower income background do not perform as well in classes as the students from upper income background. This is because student from lower income background deal with other financial and stress issues. This difference in gaining quality of education generates a certain socioeconomic gradient. This socioeconomic gradient is highly seen in other developing countries as well (Mahon, 2016). Kauts, et al., (2016) suggested that the family circle is the very first socializing agent for the kids. And they learn very much from it. If the family deals with poverty not much attention can be given to child education thereby quality of education in these societies decreases (Kauts \& Kaur, 2016). Above mentioned studies highly confer the fact that high poverty rate in developing countries of Asia leads to the poor quality of education to the individuals.

\section{H1: Poverty has significant impact on quality of education}

\subsection{Impact of fertility rate on the quality of education}

Bongaarts, et al., (2012) agreed on the fact that the decline in the rate of fertility in a country leads to the better socioeconomic development thus leading to the better quality of education (Bongaarts \& Watkins, 1996; John Charles Caldwell, 1982; Lee \& Bulatao, 1983). The trend of increased fertility rate is seen very less in urban areas where educated women have realised that fact that the reduction in the fertility brings financial wellbeing. This financial wellbeing will help their children to get quality of education. Bernstein et al, (2019) stated that rapid decrease in birth rates in a certain small and predominantly agricultural communities like Bangladesh has been entirely unexpected and is requiring a massive overhaul of the hypotheses of reduction in fertility (Hampton, 1993; Patrinos, 1990). Although the rate of fertility was formerly regulated by the higher economic class, the subsequent decrease in its rate could be the result of a regulation of fertility amongst the =society impoverished community. As poor women enter the above-mentioned process of transition (that has not yet occurred in several early-transition communities), poverty and decline in disparity have an effect on development (Bernstein, 2002).

Asian fertility declined sharply over the course of the last twenty years (John C Caldwell, 1993) . Nevertheless, over the last few decades, approximately all Asian countries have undergone a decrease in reproduction at different scales. The emergence of the change from positive to negative population growth in Asia throughout that time was evidently a common phenomenon (Gong \& Yi, 2018; Olasupo \& Idemudia, 2017). Almost Asia's entire drop in fertility is among the poorest, with largely rural and uneducated in most populated countries (Bongaarts \& Watkins, 1996) like Bangladesh, India, China, Indonesia, Sri Lanka and Vietnam Overall, the sum of their populations is $76 \%$ of Asia's populace and $60 \%$ among all developing nations. This paper uses data from the survey in Bangladesh in 2014 to explore the relationship among age at marriage, education and fertility across urban and rural women.

Fertility rate has significant impact on quality of education (Anser, Zhang, \& Kanwal, 2018; Asongu \& Asongu, 2018; Tight, 2019). The analysis of variance is used to determine the number of children born to the educated and uneducated women. Despite the poverty status in rural areas the child birth was more than in urban areas (Haq, 
JOURNAL OF SECURITY AND SUSTAINABILITY ISSUES

ISSN 2029-7017/ISSN 2029-7025 (online)

2020 Volume 9 January

http://doi.org/10.9770/jssi.2020.9.J(16)

2018). The above-mentioned studies verify the fact the increased fertility has inverse impact on the quality of education and this condition got worse in rural areas.

\section{H2: Increased fertility has significant impact on quality of education}

\subsection{Impact of Increase Population on the Quality of Education}

Asia is the most populated continent of the world. The population in Asia in 2019 is 4.61 billion and the most populated countries of the world like China, India and Pakistan resides here. The literacy rates in this region is very low than other continents. China was the least developing but most populated country in 1980s, to combat this issue Chinese government implemented one child policy. And after decades the literacy rate of China has risen up to 96.4 $\%$ in 2019. This shows that increase in population have a negative role on the quality of education. A study conducted by Sajid \& Khan proposed that larger the household the more negative will be its impact on the education. Larger families and poverty make the situation worse (Sajid \& Khan, 2016). These studies highly support the fact that population upraise decrease the quality of education. There is a direct relationship between effective governance and quality of education. Zaman at al., suggested that internationalization of the institutes should be done by the government to ensure its effectiveness. They used panel fixed effective model to evaluate the governess effectiveness with the quality of education. The study concluded that the voice and accountability together with government effectiveness effect the quality of education in the positive way (Odhiambo, 2011; Oldfield \& Baron, 2000; Pfeffer, 2015). Corruption in the education sector, ensuring better pays for the students and making funding available for every student is necessary. (Zaman, 2016). Guisan \& Exposito et al., performed a study in the middle income countries about the role of providing electricity In the educational institutions is directly proportional to the effectiveness of the government (Guisan \& Exposito, 2010). Aslam et al., studied that the quality of education in the government schools is less than the private school, the enrolment of boys in the school is more than the girls. The government of these developing countries should play there roll to resolve the issue faced by the population so that there indirect influence on the quality of education can be resolved (Aslam, 2009).

\section{H3: Increased population rate has significant impact on quality of education.}

\section{Methodology}

\subsection{Data}

The data for this study was collected about poverty, fertility rate, population and quality of education. This data was collected from several countries of Asian region and it comprised of 29 years. The databases from which data was collected include World Bank and Global Economy. These are very reliable and authentic sources from which data has been collected. After collection of data, the measurement units of each of the variables included in this study were determined.

\subsection{Model Specification}

The basic motive behind this study is to investigate and check the impact that poverty, fertility rate and increase in population have on quality of education. First of all, the variables must be classified among dependent, independent and control variables. Quality of education is a dependent variable while poverty, fertility rate and population are independent variables. Apart from these variables, two control variables have been included in the study i.e. literacy rate and per capita income. The measurement units of all the above mentioned variables are discussed here briefly. The measurement unit of quality of education is based on the satisfaction level of the students. The poverty is measured through the percentage of people that are living having less than a certain amount of money. In the same 
JOURNAL OF SECURITY AND SUSTAINABILITY ISSUES

ISSN 2029-7017/ISSN 2029-7025 (online)

2020 Volume 9 January

http://doi.org/10.9770/jssi.2020.9.J(16)

way, fertility rate is measured by the number of births per woman. Population is a variable that is measured in terms of millions of people. The control variable, literacy rate has the measurement units of the number of people that are educated in a country while the other control variable per capita income is measured by millions of US dollars. The author has made a regression equation involving all the above mentioned variables and is given as:

$$
E D U_{i t}=\alpha+\beta_{1} P O V_{i t}+\beta_{2} F E R_{i t}+\beta_{3} P O P_{i t}+\beta_{4} L I T_{i t}+\beta_{5} P C I+\varepsilon_{i t}
$$

In the above given equation, EDU shows the term quality of education, POV shows poverty, FER shows fertility rate, POP shows population, LIT shows literacy rate. PCI shows per capita income and $\varepsilon_{i t}$ is used to represent error.

\subsection{Estimation Procedure}

To analyze the collected data, the author has used several techniques and approaches such as unit root test, cointegration test, coefficient estimation test and Granger Casualty test for various purposes. The details of each of these tests are given below:

\subsubsection{Panel Unit Root Test}

The first test that is used in this study in order to analyze and scrutinize the collected data is unit root test. This test has been designed in order to find out the order of integration and stationarity of the variables involved in the study. Im Pesaran Shin IPS and Levin Lin Chu LLC are the most basic and important tests that are used for the abovementioned purpose. The preference to use these tests over the old and conventional tests is based on the fact that they resolve certain issues regarding size and power of the collected data (Levin, Lin, \& Chu, 2002). In addition, these tests provide normal standard distribution unlike of the old tests. In this particular study the author has employed LLC unit root test. Another important point that must be noted here is that LLC provides homogeneous autoregressive process while IPS provides heterogeneous autoregressive process. There are two types of hypotheses that are involved in these tests i.e. null and alternate hypothesis. The null hypothesis is characterized by the presence of unit root resulting in non-stationarity of data while the alternate hypothesis is characterized by the absence of unit root resulting in the stationarity of the collected data. The author has applied the following equation in order to use the LLC unit root test:

$$
\Delta y_{i, t}=a_{i}+\rho y_{i, t}-1+\sum_{J=1}^{p i} a_{J} \Delta y_{i, t-J}+\varepsilon_{i, t}
$$

Here $\Delta y_{i, t}$ is the difference that $\Delta y_{i, t}$ shows for $\mathrm{i}^{\text {th }}$ country for the specific time period of $\mathrm{t}$.

\subsubsection{Panel Cointegration Test}

The next test that is used by the author in this study is panel cointegration test. The basic purpose to use this particular test is to check the presence of any cointegrated as well as long run equilibrium relationships between the variables (Im, Pesaran, \& Shin, 2003). These tests are also based on the null and alternate hypothesis. In this regard, the null hypothesis indicates the idea that there is no cointegrated relationship between the variables while the alternate hypothesis indicates the idea that cointegrated relationship is present between the variables. The rejection and acceptance of these two hypotheses given and idea of evaluation of the results obtained from these tests. There are two tests that are more commonly and generally used i.e. Kao and Pedroni cointegration tests. These tests involve two approaches i.e. within dimension and between dimension approach. These approaches have some 
JOURNAL OF SECURITY AND SUSTAINABILITY ISSUES

ISSN 2029-7017/ISSN 2029-7025 (online)

2020 Volume 9 January

http://doi.org/10.9770/jssi.2020.9.J(16)

values of test statistics that show that whether the null hypothesis of no cointegration is accepted or rejected and on this basis the final results are evaluated. The author has used the following equation while applying the Kao cointegration test:

$$
y_{i, t}=\alpha_{i}+\delta_{i, t}+\beta_{1} X_{1, i, t}+\beta_{2} X_{2, i, t}+\cdots+\beta_{n} X_{n, i, t}+\varepsilon_{i, t}
$$

\subsubsection{Coefficient Estimation Test}

In the current research process, the next step is the use of coefficient estimation test for the purpose of finding out that how much impact the independent and control variables have on dependent variable i.e. quality of education. In this regard, FMOLS and DOLS are most commonly used. The author has, however, used DOLS in this particular study (Pedroni, 2001). The results of these tests involve different values for all the variables the significance level of which shows the magnitude of impact that one variable has on the other variable. It must be noted here that these two tests i.e. FMOLS and DOLS are basically derived from simple OLS test. This is because of the reason that simple OLS tests raised issues related to serial correlation and endogenous variables existence. These issues resulted in inaccurate results due to which it was necessary to find solution for this problem. Therefore, FMOLS and DOLS were developed. The author has used the following equation for DOLS coefficient estimation test:

$$
\hat{\beta}_{F M}=\left(\sum_{i=1}^{N} \sum_{t=1}^{T}\left(x_{i, t}-\bar{x}_{i}\right)^{2}\right)^{-1} \sum_{i=1}^{N}\left(\sum_{t=1}^{T}\left(x_{i, t}-\bar{x}_{i}\right) \overrightarrow{E D U}_{i, t}-T \hat{\delta}_{\varepsilon u}\right)
$$

In this equation, $\widehat{E D U}_{i, t}$ is the transformed variable of quality of education due to endogeneity correction while $\hat{\delta}_{\varepsilon u}$ represents the serial correlation correction by DOLS.

\subsubsection{Granger Casualty Test}

In the current research process, the author has applied Granger Casualty test in the last of the process in order to find out that whether casual relationships are present among the variables or not (Dumitrescu \& Hurlin, 2012). The null and alternate hypotheses are also involved in this scenario. The null hypothesis suggests the absence of casual relationship while the alternate hypothesis suggests the presence of casual relationships. These casual relationships may either unidirectional or bidirectional depending upon the value present in the results of the test. The author has used the following equation for this purpose:

$$
\begin{gathered}
x_{t}=\sum_{i=1}^{\infty} a_{i} x(t-i)+c_{1}+\mu_{1(t)} \\
x_{t}=\sum_{i=1}^{\infty} a_{i} x(t-i)+\sum_{j=1}^{\infty} b_{j} y(t-j)+c_{2}+\mu_{2(t)}
\end{gathered}
$$


JOURNAL OF SECURITY AND SUSTAINABILITY ISSUES

ISSN 2029-7017/ISSN 2029-7025 (online)

2020 Volume 9 January

http://doi.org/10.9770/jssi.2020.9.J(16)

\section{Empirical Analysis}

\subsection{Results of Panel Unit Root Test}

The results of LLC unit root test have been given in the table 1. This test was applied in order to investigate the order of integration and to check the stationary properties of the variables. According to the results presented in table 1 , it can be seen that in the level series of the table, all the variables except fertility rate and per capita income have accepted the null hypothesis and this majority of acceptance shows that in level series, unit root exists and the data is non stationary. However, in the first difference series of the table, it can be seen that all of the variables have rejected the null hypothesis, and this indicates that in this particular series the data has become stationary. This whole modification of non-stationary to stationary data has its foundations in the first difference application on the collected data. The results of this test can be concluded by stating that data was non-stationary in level series but becomes stationary once it is first differenced.

Table 1. Panel Unit Root Test - Levin Lin Chu LLC

\begin{tabular}{lll}
\hline Variable & Level & $1^{\text {st }}$ Difference \\
\hline \multirow{2}{*}{ EDU } & -4.8536 & $-3.8457^{* * * *}$ \\
& $(0.823)$ & $(0.042)$ \\
POV & -5.3946 & $-5.7357^{* *}$ \\
& $(0.364)$ & $(0.012)$ \\
FER & $-6.2974 * *$ & $-10.934^{* * *}$ \\
& $(0.045)$ & $(0.000)$ \\
POP & -4.0835 & $-9.8924 * * *$ \\
& $(0.263)$ & $(0.000)$ \\
LIT & -7.9467 & $-11.739^{* *}$ \\
& $(0.375)$ & $(0.001)$ \\
PCI & $-2.7324 * *$ & $-12.924^{* * *}$ \\
\hline
\end{tabular}

In this table, * represents that the rejection is one percent significant, ** shows that rejection is five percent significant, *** shows that rejection is ten percent significant

\subsection{Results of Panel Cointegration Test}

The Kao cointegration test was applied by the author so that the presence of cointegrated relationships can be estimated and investigated between the variables. The detailed results of this test have been given in the table 2 of the study. According to the results shown in the tables, it can be seen that different test statistics values have been given for within as well as between dimension approach. It is clearly evident that in within dimension approach, three test statistic values have rejected the null hypothesis of no cointegration. In the similar way, two test statistic values have rejected the null hypothesis in between dimension approach. Overall five test statistic values out of seven have rejected the null hypothesis and thus points towards the existence of cointegrated relationships between the variables of the study. 
JOURNAL OF SECURITY AND SUSTAINABILITY ISSUES

ISSN 2029-7017/ISSN 2029-7025 (online)

2020 Volume 9 January

http://doi.org/10.9770/jssi.2020.9.J(16)

Table 2. The KAO Panel Cointegration Test

\begin{tabular}{|c|c|c|c|c|}
\hline & Statistic & Prob. & $\begin{array}{l}\text { Weighted } \\
\text { Statistic }\end{array}$ & Prob. \\
\hline Panel v-Statistic & -3.826469 & $\overline{0.2764}$ & -3.836782 & $\overline{0.0000}$ \\
\hline Panel rho-Statistic & $2.329697 * *$ & 0.2846 & 2.873936 & 0.3886 \\
\hline Panel PP-Statistic & $-11.32979 *$ & 0.0000 & -6.293684 & 0.0002 \\
\hline Panel ADF-Statistic & $-2.134521^{*}$ & 0.0002 & -2.284689 & 0.0005 \\
\hline
\end{tabular}

Alternative hypothesis: individual AR coefs. (between-dimension)

Group rho-Statistic

Group PP-Statistic

Group ADF-Statistic

\begin{tabular}{ll} 
Statistic & Prob. \\
\hline \hline $4.182369 *$ & 0.0000 \\
-19.23486 & 0.0000 \\
$-1.238649 * *$ & 0.0237
\end{tabular}

In this table, * represents that the rejection is one percent significant, ** shows that rejection is five percent significant

\subsection{Results of Coefficient Estimation Test}

When the order of integration and cointegrated relationships has been identified, the next important step is to measure the relationships between the variables. For this purpose, the author has applied DOLS coefficient estimation technique, the results of which have been given in the table 3 of the study. According to this table, the impact of poverty on education quality has been found as significant. In other words, with increase of one percent of poverty, education quality is supposed to decrease by $28.3 \%$. In addition, the impact of fertility has been found as insignificant on quality of education. The impact of population increase has significant impact on quality of education and with one percent increase in population; the quality of education will decrease by $23.7 \%$. Moreover, the impact of one control variable, per capita income has also been found as significant in context of education quality. However, the impact of other control variable, literacy rate has been found as insignificant.

Table 3. DOLS Regression

\begin{tabular}{lllll}
\hline Variable & Coefficient & Std. Error & t-Statistic & Prob. \\
\hline POV & $0.283863 * *$ & 0.2836 & 2.283764 & 0.0000 \\
FER & 0.207386 & 0.2863 & 3.927672 & 0.0002 \\
POP & $0.237942 * *$ & 0.8463 & 3.472638 & 0.0003 \\
LIT & 0.113809 & 0.3512 & 2.283648 & 0.8771 \\
PCI & $0.236873 *$ & 0.9376 & 1.283647 & 0.0002 \\
Constant & 0.236829 & 0.1837 & 2.394782 & 0.0003 \\
R-squared & 0.482648 & & & \\
Adjusted R-squared & 0.137684 & & & \\
F-statistic & 32.24894 & & & \\
Prob(F-statistic) & 0.000000 & & & \\
Durbin-Watson stat & 2.826389 & & & \\
\hline
\end{tabular}

In this table, * represents one percent significance level, ** shows five percent significance level 
JOURNAL OF SECURITY AND SUSTAINABILITY ISSUES

ISSN 2029-7017/ISSN 2029-7025 (online)

2020 Volume 9 January

http://doi.org/10.9770/jssi.2020.9.J(16)

\subsection{Results of Granger Casualty Test}

The results of Granger casualty test have been presented in table 4 of the study. This test was employed in order to find out the casual relationships between variables of the study. The results of this test show that there are casual relationships present among various variables such as from poverty to literacy rate, from population to poverty and per capita income to name a few. These casual relationships can either be unidirectional or bidirectional depending upon the values presented in the table.

Table 4. Granger Casualty Test

\begin{tabular}{lllllll}
\hline Variables & EDU & POV & FER & POP & LIT & PCI \\
\hline EDU & & 0.374 & 0.826 & $0.283^{*}$ & 0.923 & 0.183 \\
POV & $0.726^{*}$ & & 0.735 & 0.926 & $0.826^{*}$ & 0.826 \\
FER & 0.275 & $0.836^{*}$ & & 0.386 & 0.836 & 0.825 \\
POP & $0.273^{* *}$ & $0.284^{*}$ & 0.286 & & 0.725 & $0.524^{*}$ \\
LIT & $0.286^{*}$ & 0.384 & $0.243^{*}$ & $0.283^{*}$ & & 0.274 \\
PCI & 0.587 & 0.864 & 0.926 & 0.293 & 0.234 & \\
\hline
\end{tabular}

In this table, * represents one percent significance level, ** shows five percent significance level

\section{Discussion and Conclusion}

\subsection{Discussion}

As the study was conducted in order to investigate and explore the impact of poverty, fertility rate and population increase in presence of two control variables i.e. literacy rate and per capita income, some hypotheses were generated for this purpose. The first hypothesis was that poverty has significant impact on quality of education. This hypothesis was accepted in accordance with the results as well as the reference from past study (Van der Berg, 2008). The second hypothesis was that fertility rate has significant impact on quality of education and this hypothesis was rejected in this study. This result is similar to the one present in the past study (Shirahase, 2000). The last hypothesis was that population increase has significant impact on education quality. This hypothesis was also accepted by the author. This result is in accordance with a research conducted in the past (Maeshiro et al., 2010). The impact of one control variable, per capita income has also been found as significant on quality of education which is same as shown in a past study (Krueger, 1968).

\subsection{Conclusion}

Poverty, fertility rate and population increase are those aspects which may have adverse impacts on many things including education quality. This study has been conducted in order to study and analyze the impact of these three aspects on quality of education in Asian countries. The data for analysis purpose was collected from Asian countries for 29 years. Many tests and approaches were used in order to scrutinize this data for various purposes. The most important tests include panel unit root test, panel cointegration test, coefficient estimation test and Granger casualty test. When the results of these tests were interpreted, it was discovered that poverty and population increase have significant impact on education quality, but the impact of fertility rate was found as insignificant. Several casual relations in different directions were also discovered by the results of casualty test. The author has discussed some implications as well as limitations in the last of the study. Some recommendations have also been given by the author that may assist the other researchers in order to improve their researches. 


\section{JOURNAL OF SECURITY AND SUSTAINABILITY ISSUES}

ISSN 2029-7017/ISSN 2029-7025 (online)

2020 Volume 9 January

http://doi.org/10.9770/jssi.2020.9.J(16)

\subsection{Implications}

The author has identified some of the benefits and implications of this study. In theoretical implications, it can be stated that this study has provided enough literature and knowledge about the aspects such as poverty, fertility rate and population increase in context of their impact on education quality. The practical implication of this study is that it has provided guidance to the educational institutes and education related other departments to cope with the problems of poverty, fertility rate and population increase so that the quality of education may be increased in these countries. This study has also provided assistance and guidance to the policy making departments of government to make such policies and regulations that put a control on poverty, fertility rate and population increase in order to enhance the quality of education in these countries.

\subsection{Limitations and Future Research Indications}

The author has identified and discussed some important limitations of this study so that the future researchers may improve them in their own studies to be conducted in the future. In this regard, other futures may use tests and approaches that are in accordance with the data collected and are not used in this study. They may use other variables or other combination of variables that has not been used in this study. The sample size must also be increased in order to broaden the spectrum of the study. Countries other than Asian countries may be added in the study to increase the scope of the study by other authors.

\section{References}

Aghion, P. (1999). Bacchetta, P. Banerjee, A.

Aghion, P., \& Howitt, P. (1992). A Model of Growth through.

https://dash.harvard.edu/bitstream/handle/1/12490578/A\%20Model\%20of\%20Growth\%20through\%20Creative\%20Destruction.pdf

Anser, M. K., Zhang, Z., \& Kanwal, L. (2018). Moderating effect of innovation on corporate social responsibility and firm performance in realm of sustainable development. Corporate Social Responsibility and Environmental Management, 25(5), 799-806.

$\underline{\text { https://doi.org/10.1002/csr.1495 }}$

Aslam, M. (2009). The relative effectiveness of government and private schools in Pakistan: are girls worse off? Education Economics, 17(3), 329-354. https://doi.org/10.1080/09645290903142635

Asongu, S., \& Asongu, N. (2018). Comparative determinants of quality of growth in developing countries. International Journal of Happiness and Development, 4(1), 65-89. https://doi.org/10.1504/IJHD.2018.090491

Bernstein, S. (2002). Population and poverty: some perspectives on Asia and the pacific: Asia-Pacific. Asia-Pacific population journal / United Nations, 17(4), 31-48 https://doi.org/10.18356/dc0c4149-en

Bongaarts, J., \& Watkins, S. C. (1996). Social interactions and contemporary fertility transitions. Population and development review, 639682. https://doi.org/10.2307/2137804

Caldwell, J. C. (1982). Theory of fertility decline. https://doi.org/10.2307/1972905

Caldwell, J. C. (1993). The Asian fertility revolution: its implications for transition theories.

Dumitrescu, E.-I., \& Hurlin, C. (2012). Testing for Granger non-causality in heterogeneous panels. Economic Modelling, 29(4), 14501460. https://doi.org/10.1016/j.econmod.2012.02.014

Efendi, R., Indartono, S., \& Sukidjo, S. (2019). The Relationship of Indonesia's Poverty Rate Based on Economic Growth, Health, and Education. International Journal of Multicultural and Multireligious Understanding, 6(2), 323-330.

https://ijmmu.com/index.php/ijmmu/manager/setup/dx.doi.org/10.18415/ijmmu 


\section{JOURNAL OF SECURITY AND SUSTAINABILITY ISSUES ISSN 2029-7017/ISSN 2029-7025 (online) \\ 2020 Volume 9 January \\ http://doi.org/10.9770/jssi.2020.9.J(16)}

Fields, G. S. (1980). Education and income distribution in developing countries: A review of the literature.

Gap, G. G. (2017). World economic forum. Cologny/Geneva.

Girdzijauskaite, E., Radzeviciene, A., Jakubavicius, A. (2019). Impact of international branch campus KPIs on the university competitiveness: FARE method, Insights into Regional Development, 1(2), 171-180. https://doi.org/10.9770/ird.2019.1.2(7)

Gong, T., \& Yi, Y. (2018). The effect of service quality on customer satisfaction, loyalty, and happiness in five Asian countries. Psychology \& Marketing, 35(6), 427-442. https://doi.org/10.1002/mar.21096

Guisan, M.-C., \& Exposito, P. (2010). Health expenditure, education, government effectiveness and quality of life in Africa and Asia. Regional and Sectoral Economic Studies, 10(1), 115-126.

Güneş, P. M. (2016). The impact of female education on teenage fertility: evidence from Turkey. The BE journal of economic analysis \& policy, 16(1), 259-288. https://doi.org/10.1515/bejeap-2015-0059

Hampton, G. M. (1993). Gap analysis of college student satisfaction as a measure of professional service quality. Journal of professional services marketing, 9(1), 115-128. https://doi.org/10.1300/J090v09n01_10

Hanif, N., \& Arshed, N. (2016). Relationship between school education and economic growth: SAARC countries. International Journal of Economics and Financial Issues, 6(1), 294-300.

Hanushek, E. A., \& Kimko, D. D. (2000). Schooling, labor-force quality, and the growth of nations. American economic review, 90(5), 1184-1208. https://doi.org/10.1257/aer.90.5.1184

Haq, I. (2018). Relationship between age at marriage, education and fertility among residence of Bangladesh. Am J Soc Sci Res, 4(2), 3339.

Hardoon, D. (2017). An Economy for the 99\%-It's time to build a human economy that benefits everyone, not just the privileged few (Oxfam Briefing Paper): Oxford: Oxfam International. Retrieved from https://www. oxfam. org/sites ....

Humbatova, S.I., Gadim-Oglu Hajiyev, N. (2019). The role of spending on education and science in sustainable development. Entrepreneurship and Sustainability Issues, 7(2), 1704-1727. http://doi.org/10.9770/jesi.2019.7.2(63)

Im, K. S., Pesaran, M. H., \& Shin, Y. (2003). Testing for unit roots in heterogeneous panels. Journal of econometrics, 115(1), 53-74. https://doi.org/10.1016/S0304-4076(03)00092-7

Jermsittiparsert, K. \& Sawasdee, A. (2012). Formal Education for Non-Thai or Undocumented Person in Thailand amidst the Challenge of Nationalism and Transnationalism: A Case Study of Wat Sirimongkhol School, Samut Sakhon Province. Kasetsart Journal - Social Sciences, 33(2), 203-213.

Kauts, A., \& Kaur, B. (2016). A study of children's behaviour in relation to family environment and technological exposure at pre primary stage. MIER Journal of Educational Studies, Trends and Practices, 1(2).

Krueger, A. O. (1968). Factor endowments and per capita income differences among countries. The economic journal, 78(311), 641-659. https://doi.org/10.2307/2229388

Latif, A., Choudhary, A., \& Hammayun, A. (2015). Economic effects of student dropouts: A comparative study. Journal of global economics. https://doi.org/10.4172/2375-4389.1000137

Lee, R. D., \& Bulatao, R. A. (1983). The demand for children: A critical essay. Determinants of fertility in developing countries: a summary of knowledge, 233-287.

Levin, A., Lin, C.-F., \& Chu, C.-S. J. (2002). Unit root tests in panel data: asymptotic and finite-sample properties. Journal of econometrics, 108(1), 1-24. https://doi.org/10.1016/S0304-4076(01)00098-7 


\section{JOURNAL OF SECURITY AND SUSTAINABILITY ISSUES ISSN 2029-7017/ISSN 2029-7025 (online) \\ 2020 Volume 9 January \\ http://doi.org/10.9770/jssi.2020.9.J(16)}

Maeshiro, R., Johnson, I., Koo, D., Parboosingh, J., Carney, J. K., Gesundheit, N., . . Finkelstein, J. A. (2010). Medical education for a healthier population: reflections on the Flexner Report from a public health perspective. Academic Medicine, 85(2), 211-219. https://doi.org/10.1097/ACM.0b013e3181c885d8

Mahon, R. (2016). Early childhood education and care in global discourses. The handbook of global education policy, 224. https://doi.org/10.1002/9781118468005.ch12

Mankiw, N. G., Romer, D., \& Weil, D. N. (1992). A contribution to the empirics of economic growth. The quarterly journal of economics, 107(2), 407-437. https://doi.org/10.2307/2118477

Odhiambo, G. O. (2011). Higher education quality in Kenya: A critical reflection of key challenges. Quality in Higher Education, 17(3), 299-315. https://doi.org/10.1080/13538322.2011.614472

Olasupo, M. O., \& Idemudia, E. S. (2017). Socio-economic and socio-demographic determinants of quality of life among young adults in South West Nigeria. Gender and Behaviour, 15(4), 9997-10009.

Oldfield, B. M., \& Baron, S. (2000). Student perceptions of service quality in a UK university business and management faculty. Quality Assurance in education, 8(2), 85-95. https://doi.org/10.1108/09684880010325600/full/html

Patrinos, H. A. (1990). The privatization of higher education in Colombia: Effects on quality and equity. Higher Education, 20(2), 161-173. https://doi.org/10.1007/BF00143699

Pedroni, P. (2001). Fully modified OLS for heterogeneous cointegrated panels Nonstationary panels, panel cointegration, and dynamic panels (pp. 93-130): Emerald Group Publishing Limited. https://doi.org/10.1016/S0731-9053(00)15004-2/full/html

Pfeffer, F. T. (2015). Equality and quality in education. A comparative study of 19 countries. Social science research, 51, $350-368$. https://doi.org/10.1016/j.ssresearch.2014.09.004

Roser, M., \& Ortiz-Ospina, E. (2016). Literacy. Our World in Data.

Sajid, G., \& Khan, M. (2016). Determinants of Primary School Enrollment in Pakistan: Is Poverty a Hurdle in the Way of Educational Attainment? The Pakistan Journal of Social Issues, 7, 1-18.

Shirahase, S. (2000). Women's increased higher education and the declining fertility rate in Japan. Review of population and social policy, $9(2000), 47-63$.

Solow, R. M. (1956). A contribution to the theory of economic growth. The quarterly journal of economics, 70(1), 65-94. https://doi.org/10.2307/1884513

Tight, M. (2019). Globalization and internationalization as frameworks for higher education research. Research Papers in Education, 1-23. https://doi.org/10.1080/02671522.2019.1633560

Van der Berg, S. (2008). Poverty and education. Education policy series, 10, 28. https://doi.org/10.1016/j.stueduc.2008.07.005

Zaman, K. (2016). Quality guidelines for good governance in higher education across the globe. Pacific Science Review B: Humanities and Social Sciences. https://doi.org/10.1016/j.psrb.2016.01.001 
JOURNAL OF SECURITY AND SUSTAINABILITY ISSUES

ISSN 2029-7017/ISSN 2029-7025 (online)

2020 Volume 9 January

http://doi.org/10.9770/jssi.2020.9.J(16)

Waleerak SITTISOM is a Lecturer of Suan Sunandha Rajabhat University, Thailand. Her research areas are Business Administration, Supply Chain Management, and Logistic.

ORCID ID: orcid.org/0000-0002-9667-3730

Register for an ORCID ID:

https://orcid.org/register

This work is licensed under the Creative Commons Attribution International License (CC BY).

http://creativecommons.org/licenses/by/4.0/

(c) (1) 0 pen Access 